\title{
Botanical Studies within the PABITRA Wet-Zone Transect, Viti Levu, Fiji ${ }^{1}$
}

\author{
Gunnar Keppel ${ }^{2}$
}

\begin{abstract}
Botanical studies along mountain-to-sea transects are a key component of the Pacific-Asia Biodiversity Transect (PABITRA) project. For the Fiji PABITRA Wet-Zone Transect, it is suggested that four basic categories of biodiversity data (species inventory, plant community description, ecological data on the species and community level, and long-term monitoring) be collected within the seven biodiversity study sites (Mt. Tomaniivi/Wabu, Monasavu, Sovi Basin, Waisoi, Waibau, Savura, and Nasoata/Valolo Islands) covering an elevational gradient from sea level to $1,300 \mathrm{~m}$. Currently, Sovi and Waibau are without data, except for vegetation descriptions based on aerial photographs. However, data from baseline surveys is now available for Sovi. Most of the data available on Mt. Tomaniivi/Wabu and Savura are extrapolated from collections and studies in adjacent areas, but in both areas data collection has recently begun. Only Waisoi and Nasoata/Valolo have species checklists and descriptions of the various plant communities, with ecological studies having been conducted only in the former. Because basic data (species lists, plant communities) are lacking in many areas, obtaining such data is a primary objective of PABITRA in Fiji. Other issues that should be considered are inclusion of other sites in the network of focal sites and a standardized way of data entry and basic data analysis.
\end{abstract}

FiJI, As AN oceanic island group located between $15^{\circ}$ and $22^{\circ} \mathrm{S}$ and $177^{\circ} \mathrm{W}$ and $175^{\circ} \mathrm{E}$ in the South Pacific Ocean (Figure 1), has a unique flora that is a depauperate and disharmonic version of the Malesian flora (van Balgooy 1971). The archipelago comprises about 500 named islands with an estimated land area of $18,325 \mathrm{~km}^{2}$, covering a total area of about $650,000 \mathrm{~km}^{2}$. Viti Levu $\left(10,388 \mathrm{~km}^{2}\right)$ and Vanua Levu $\left(5,535 \mathrm{~km}^{2}\right)$ compose the bulk of the land area (Mueller-Dombois and Fosberg 1998). Several botanical explorations (summarized by Smith 1979) resulted in two floras: the first by Seemann (1865-1873), followed by the more comprehensive Flora Vitiensis Nova (Smith 1979, 1981, 1985, 1988,

\footnotetext{
${ }^{1}$ Manuscript accepted 23 April 2004.

${ }^{2}$ Biology Department, School of Pure and Applied Sciences, University of the South Pacific, Suva, Fiji (e-mail: keppel_g@usp.ac.fj).
}

Pacific Science (2005), vol. 59, no. 2:165-174

(C) 2005 by University of Hawai'i Press

All rights reserved
1991, 1996). Mainly based on Smith's flora, Watkins (1995) reported about 2,225 plant species from Fiji with 58\% (or about 1,290 species) being native, of which $63 \%$ (or some 813 species) are considered endemic. However, Ash (1992) reported 1,769 native species with about 400 endemics (22\%). In any case, these values need revision because of description of new species (e.g., Fuller et al. 1997, Fuller and Dowe 1999), amalgamation of species (e.g., Whitmore 1980), introduction of new species (e.g., Keppel 1999), and reported range extension for species previously thought to be endemic to Fiji (e.g., Wheatley 1992).

Despite the extensive documentation of Fiji's flora, vegetation and ecological studies are few. Ash (1992) summarized most of these studies but omitted some, such as those on Mt. Korobaba (Kirkpatrick and Hassal 1985, Hassal and Kirkpatrick 1985) and the Sigatoka Sand Dunes (Kirkpatrick and Hassal 1981). Berry and Howard $(1973 a, b)$ conducted an inventory of the various forest types based on aerial photographs mainly for forestry purposes. They identified 41 forest 


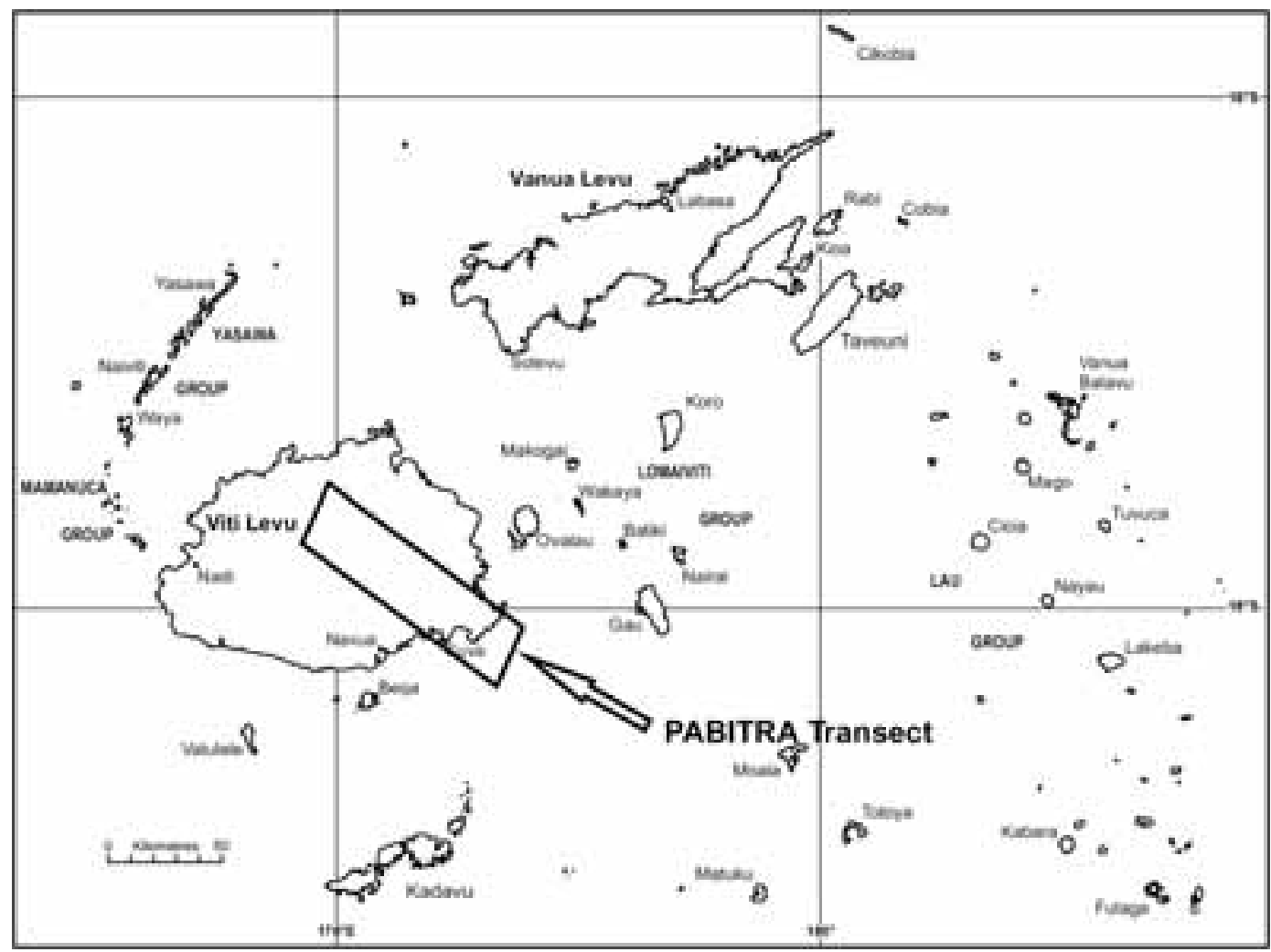

Figure 1. Approximate location of the PABITRA Wet-Zone Transect in the Fiji Group.

types. Unfortunately their account does not include a detailed map that shows the various vegetation types in Fiji. Although their study provided much information on the likely distribution of the various forest types in Fiji, field verification of forest types was restricted to certain sample locations. It is therefore questionable to what degree the results can be extrapolated to remote areas such as the Sovi Basin and the Wabu catchment. Also, because the study was conducted for forestry purposes, it focused on timber species. The various vegetation types in Fiji were identified and summarized by Mueller-Dombois and Fosberg (1998).

Fiji was one of the original transects of the Pacific-Asia Biodiversity Transect network (PABITRA) proposed at the 9th Pacific Science Inter-Congress in November 1998 in Taipei, Taiwan (Mueller-Dombois et al. 1999), and was designated as a Gateway Site of the PABITRA project at the 19th Pacific Science Congress in Sydney in July 1999. Because Fiji consists of more than 500 islands that compose a land area of more than 18,000 $\mathrm{km}^{2}$ within a total area of about $650,000 \mathrm{~km}^{2}$, a representative area had to be selected. A transect stretching from the highest peak, Mt. Tomaniivi (formerly Mt. Victoria), on the largest island, Viti Levu, to the barrier reefs beyond the delta of Fiji's largest river, the Rewa, was chosen because it best satisfied the objectives of PABITRA (MuellerDombois et al. 1999). Because this transect still includes a total area of more than 2,000 $\mathrm{km}^{2}$, representative sites at which studies will be concentrated (here called "focal sites") were chosen. Seven focal sites (Mt. 


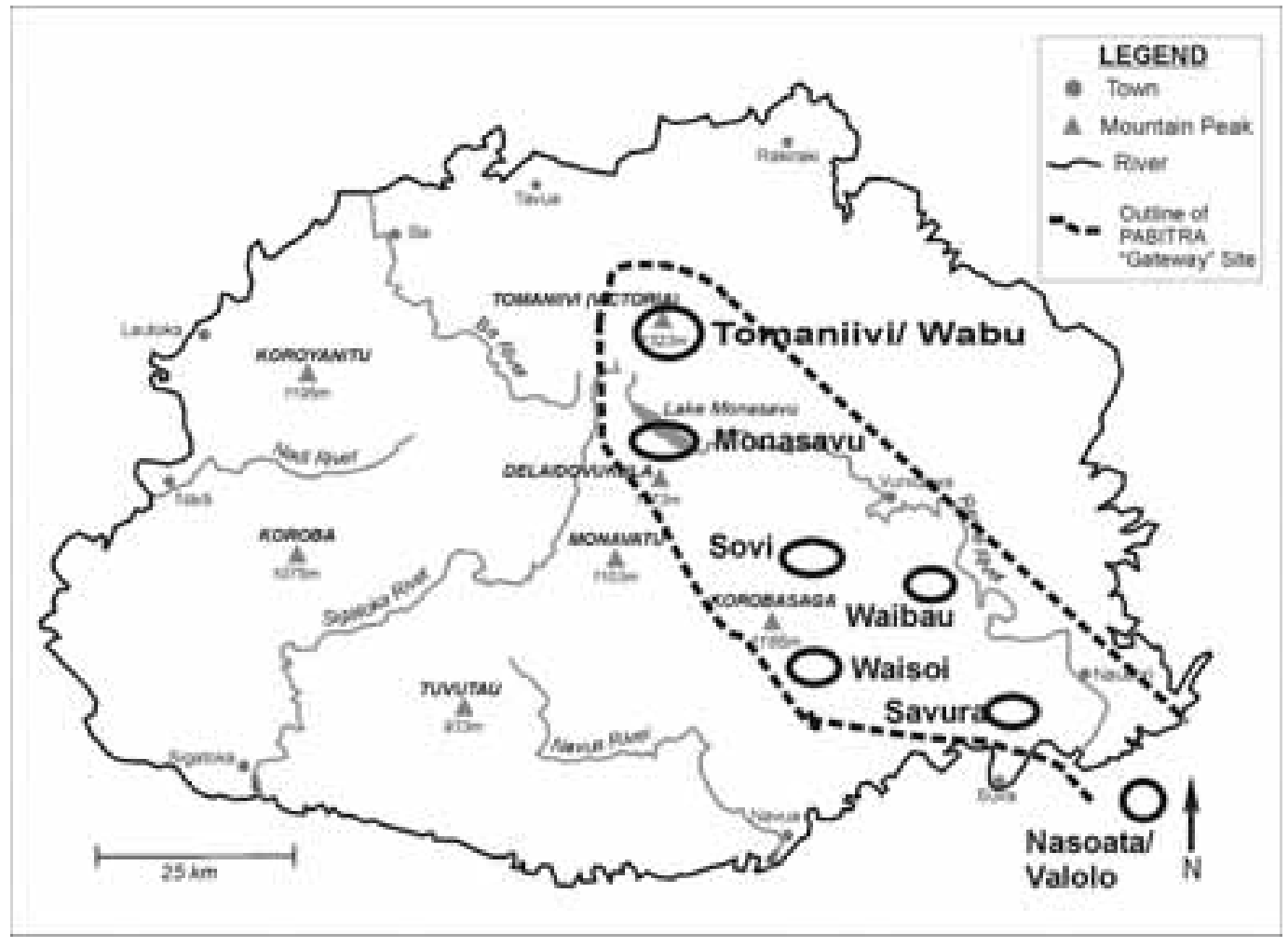

Figure 2. Outline of the Fiji PABITRA Gateway Transect (dashed lines) and the seven focal sites (circles).

Tomaniivi/Wabu, Monasavu, Sovi Basin, Waisoi, Waibau, Savura, and Nasoata/Valolo Islands [see Figure 2]), representing the range of ecosystems present in the transect, have been identified and initial work on some of them has commenced.

In this paper I review available botanical information within the Fiji PABITRA Gateway Transect to determine the "status quo" of botanical knowledge and to suggest necessary and possible future directions of research. The seven intended focal areas are discussed separately with respect to what I perceive as the major current goals for botanical studies within the Fiji focal sites: inventorying tracheophytes, analyzing plant communities, obtaining ecological data on species and communities, and initiating permanent plots for long-term monitoring.

\section{MATERIALS AND METHODS}

Information on the various focal areas of the PABITRA Gateway Transect was collected from existing literature, unpublished data, and personal communications from local researchers.

\section{RESULTS}

\section{Mt. Tomaniivi/Wabu}

This focal site includes two nature reserves, Tomaniivi (Fiji's highest mountain at $1,323 \mathrm{~m}$ and the surrounding slopes) and Wabu. Tomaniivi consists mainly of montane rain forest, and Wabu is mostly composed of montane rain forest dominated by Agathis macrophylla, a forest type restricted in Fiji to the Wabu Creek valley and small pockets of 
TABLE 1

Summary of Floristic Composition at Four Focal Sites along the PABITRA Wet-Zone Transect on Viti Levu

\begin{tabular}{|c|c|c|c|c|}
\hline & Tomaniivi $^{a}$ & Waisoi $^{b}$ & Savura $^{c}$ & Nasoata $^{c}$ \\
\hline & \multicolumn{4}{|c|}{ Total No. of Species } \\
\hline & 879 & 426 & 587 & 119 \\
\hline \% Indigenous & 93 & 86 & 95 & 75 \\
\hline \% Endemic of Indigenous Species & 53 & 49 & 52 & 9 \\
\hline Ferns & 185 & 23 & 117 & 12 \\
\hline Gymnosperms & 7 & 2 & 5 & - \\
\hline Monocotyledons & 179 & 23 & 93 & 24 \\
\hline Dicotyledons & 508 & 53 & 345 & 64 \\
\hline
\end{tabular}

${ }^{a}$ R. R. Thaman, G.K., Tuiwawa, B. Thaman, Naikatini, and Wilson (unpubl. data).

$b$ Tuiwawa (1999).

${ }^{c}$ Keppel et al. (2005, this issue).

${ }^{d}$ Thaman et al. (2005, this issue).

the Nadarivatu catchment at about $900 \mathrm{~m}$. Other common species include Calophyllum vitiense, Endospermum macrophyllum, and Parinari insularum (Berry and Howard 1973a,b). As already mentioned, this information is based mainly on aerial photographs but recent collection trips to the Wabu Reserve should soon result in a preliminary plant list (M. V. Tuiwawa, pers. comm.).

To obtain an estimate of the species that could be expected from this area, R. R. Thaman, G.K., Tuiwawa, B. Thaman, Naikatini, and Wilson (unpubl. data) prepared a list of all collections of seed plants from Nadarivatu and Mt. Tomaniivi cited in Smith (1979, 1981, 1985, 1988, 1991) and Brownlie (1977) and recorded 879 vascular plant species. Indigenous species numbered 816 (93\%) and of these 396 (45\%) were endemic. Dicotyledons composed $58 \%$ of all species, with ferns, monocotyledons, and gymnosperms contributing 21,20 , and $1 \%$, respectively (Table 1 ).

Of all the focal sites, Mt. Tomaniivi/ Wabu can be expected to have the highest number of species (Table 1). Therefore, a comprehensive species checklist for the Wabu and the Tomaniivi Reserves needs to be compiled, a process that has already begun. This will then form the basis for ecological and community studies. The plant inventory will also be necessary for setting up an altitudinal transect from Mt. Tomaniivi into the Wabu watershed.

\section{Monasavu}

Monasavu is the name of Fiji's biggest lake, which was created in 1982 , when a dam to produce electricity was constructed (Tuiwawa 2005 , this issue). It was the last of the focal sites to be designated, after a visit of the participants of the Asia-Pacific Network for Global Change/PABITRA Joint Analysis Workshop in Fiji in late November 2002. This decision was based on the presence of extensive stands of cloud forest and the accessibility of the site. Because the dam generates most of the electricity for Viti Levu, Fiji's largest island, it has housing and a welldeveloped road system. The latter will allow establishing a weather station in the cloud forest.

Considering its accessibility, surprisingly little data are available for this focal site. Hassal (1980) studied the forests and stream-bank formations along the Wainisavulevu Creek, a tributary of the Monasavu Dam. He used 1m-wide transects to $3 \mathrm{~m}$ above the water level on each side of the stream and also made comments about the cloud forest near the creek; these could be used for further studies. A total of 92 species (30 ferns, 2 gymnosperms, 20 monocotyledons, and 40 dicotyledons), 19 of which were introduced, was reported and no distinct riparian vegetation was observed, although there were certain species restricted to riverine locations. 
TABLE 2

Forest Types Described from the Sovi Basin (after Berry and Howard 1973a,b)

\begin{tabular}{|c|c|c|c|}
\hline Code & Forest Type & Topography & Dominant Species \\
\hline $\mathrm{C} 1$ & $\begin{array}{l}\text { Well-stocked } \\
\text { mixed forest }\end{array}$ & Moderate to steep short slopes & Endospermum macrophyllum, Myristica spp. \\
\hline $\mathrm{CY}$ & $\begin{array}{l}\text { Well-stocked sacau } \\
\text { forest }\end{array}$ & Upper slopes and ridges & $\begin{array}{l}\text { Palaquium hornei (dominant), Calophyllum vitiense, } \\
\text { Agathis macrophyllum, Endospermum } \\
\text { macrophyllum, Myristica spp., Syzygium spp., } \\
\text { Cleistocalyx spp., Heritiera ornithocephala, } \\
\text { Garcinia myrtifolia, Burseraceae }\end{array}$ \\
\hline G & $\begin{array}{l}\text { Moderately stocked } \\
\text { mixed forest }\end{array}$ & $\begin{array}{l}\text { Edge of catchment immediately } \\
\text { below steeply rising hills }\end{array}$ & Endospermum macrophyllum, Myristica spp. \\
\hline KV & $\begin{array}{l}\text { Moderately stocked } \\
\text { kauvula-sa forest }\end{array}$ & Gentle to moderate slopes & $\begin{array}{l}\text { Endospermum macrophyllum, Parinari insularum, } \\
\text { Bischofia javanica }\end{array}$ \\
\hline SK & $\begin{array}{l}\text { Moderately to well } \\
\text { stocked sacau- } \\
\text { yaka forest }\end{array}$ & Moderate to steep slopes & Palaquium hornei, Dacrydium nidulum \\
\hline CS & $\begin{array}{l}\text { Moderately stocked } \\
\text { forest }\end{array}$ & Long, very steep slopes & $\begin{array}{l}\text { Several species, with major timber species } \\
\text { composing smaller volumes }\end{array}$ \\
\hline GS & Low-stocked forest & Short, very steep slopes & $\begin{array}{l}\text { Syzygium spp., Cleistocalyx spp., Calophyllum spp., } \\
\text { Agathis macrophyllum, Dysoxylum spp., Bischofia } \\
\text { javanica, Dendrocnide barveyi, and species of } \\
\text { Trichospermum }\end{array}$ \\
\hline $\mathrm{S} 1$ & $\begin{array}{l}\text { Low-stocked open } \\
\text { canopy woodland }\end{array}$ & Very steep slopes & Bischofia javanica, Endospermum macrophyllum \\
\hline
\end{tabular}

Because cloud forests seem to be very susceptible to climate change (Loope and Giambelluca 1998, Still et al. 1999), setting up permanent plots should be considered another priority, because this would allow monitoring of vegetation changes associated with climate change.

\section{Sovi Basin}

The Sovi Basin is a remote inland basin covered with inland lowland rain forest. Here, based on aerial photographs (Berry and Howard 1973a,b), eight different forest types were recognized for forestry purposes (Table 2). Because this focal site can only be reached by a 6-hr walk from the nearest village, it is unlikely that the data were verified in the field. An initial 2-week-survey of the southeastern portion of the basin in May 2003 (Keppel 2003) described five forest types based on topography and disturbance levels. These five forest types did not correspond well with those previously described by Berry and Howard $(1973 a, b)$, probably because of the different objectives of the two studies. It also appears that these forests are not as pristine as suggested (Lees 1989), because several old village sites were identified. The identification of specimens collected from that expedition is almost completed and more extensive data analysis will commence upon completion of the identification process.

\section{Waisoi}

Although only a single, extensive study (Tuiwawa 1999) was conducted in Waisoi, it is the focal site with most information currently available. Of the 426 identified vascular plants reported, $86 \%$ were indigenous $(49 \%$ of which are endemic [see Table 1]). Tuiwawa (1999) selected a supposedly pristine area toward the base of the Korobasaga Range. He sampled shrubs and trees of $1 \mathrm{~cm}$ or more (diameter at breast height [DBH]). He set up 10 by $10 \mathrm{~m}$ plots (plot size determined using nested plot technique for establishing minimal area [Mueller-Dombois and Ellenberg 2002]) in four different forest types (river flats, slopes, ridges, and quasi-montane forest) totaling $6,000 \mathrm{~m}^{2}$. The quasi-montane forest 
was the most distinct vegetation type (Jaccard Index, $I=59-68)$, followed by the ridge forest $(I=73-74)$; the river flats and slopes were comparatively similar. Creek flats were dominated by Endospermum macrophyllum, species of Cyathea, Doliocholobium latifolium, and Saurauria rubicunda. Some native species that are often associated with disturbed sites, such as Grewia crenata and Ficus barclayana, were also found there. Calophyllum vitiense, Degeneria vitiense, Endospermum macrophyllum, two species of Syzygium, Gironniera celtidifolia, Cyathea spp., and Psychotria storckii dominated the slope forest type. The ridge-top forest had no dominant species (using 10\% relative abundance), but more common species included Garcinia myrtifolia, Psychotria confertiloba, Psychotria storckii, Syzygium spp., Calophyllum vitiense, Myristica gillespieana, and Tapeinospermum clavatum. The quasimontane forest had the lowest density of tree species, and dominant elements included Podocarpus affinis, Syzygium spp., Cleistocalyx spp., and Cyrtandra jugalis.

There is potential for additional work in Waisoi. Studies could be expanded to include naturally and anthropogenically disturbed sites. Also, the area sampled can be extended and permanent plots need to be initiated. Considering the existing base of information (Tuiwawa 1999), there is also great potential for additional ecological studies.

\section{Waibau}

This is an agricultural area composed of cultivated land mixed with shrub- and grassland (Berry and Howard 1973a,b), with occasional remnants of lowland rain forest. It is located in the valley of the Rewa River and its contributing streams. This focal site is not yet rigidly defined and currently lacks any information and the collection of basic vegetation data. An inventory of species and vegetation types present and a mapping of the different agricultural systems is needed.

\section{Savura}

The Savura focal site includes two adjacent forest reserves (Vago and Savura) that are catchment areas for much of Suva's water supply. Because of its comparative accessibility, this focal area has been subject to previous ecological studies investigating the demography of Balaka macrocarpa Burret (Ash 1988) and Cyatbea bornei Baker (Copel.) (Ash 1987). Despite this, no species inventory of this lowland rain forest has been carried out. However, an altitudinal transect was conducted on adjacent Mt. Korobaba (Hassal and Kirkpatrick 1985, Kirkpatrick and Hassal 1985), which is similar in altitude to Mt. Nakobalevu in the Savura focal site. Keppel et al. (2005, this issue) combined data from that study with collections reported by Smith (1979, 1981, 1985, 1988, 1991), Brownlie (1977), and the database of the South Pacific Regional Herbarium. Their data suggest that the vegetation is similar to that of Waisoi (Table 1). Kirkpatrick and Hassal (1985) also identified five altitudinal vegetation zones (Figure 3).

Currently, a permanent plot that is anticipated to be 10 to 16 ha in size, following Centre for Tropical Forest Science (CTFS) protocol (Condit 1998), is being created through a joint project between the University of the South Pacific and the Fiji Forestry Department (Keppel et al. 2005, this issue). It is anticipated that the initial census of this forest plot will be completed by early 2005 . Data obtained from this project should be supplemented by assessing additional plots within the focal site. To facilitate further comparions, these plots could ideally be located at altitudes similar to those of the study sites from Mt. Korobaba (Kirkpatrick and Hassal 1985).

\section{Nasoata/Valolo (Rewa Delta)}

Nasoata Island and the neighboring island of Valolo in the mouth of the Rewa River have been chosen as the focal site in the Rewa Delta. In addition to being a focal site of PABITRA, these two islands are currently earmarked to become the first areas in Fiji to be protected under the Convention on Wetlands (Ramsar, Iran, 1971), an intergovernmental treaty for the worldwide protection of wetlands. The vegetation on Nasoata consists 


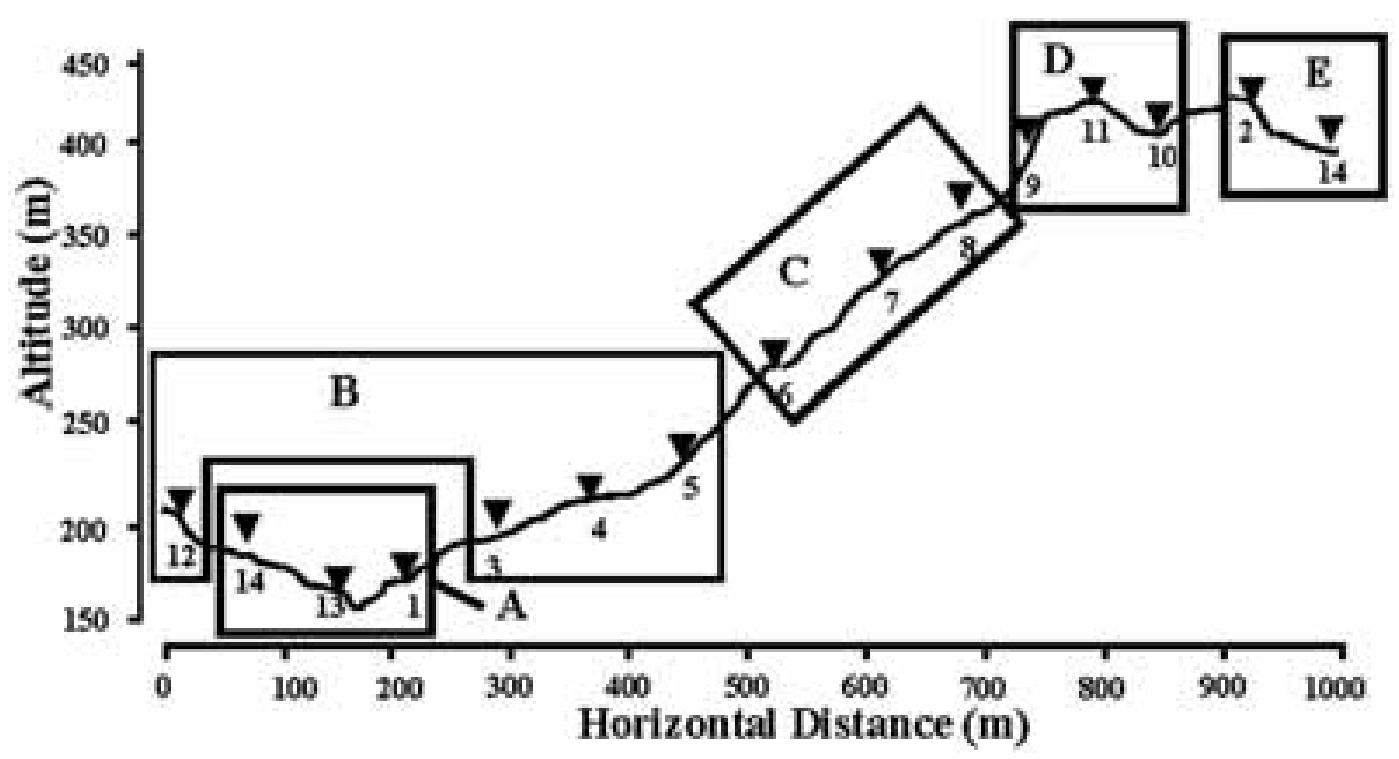

Figure 3. Distribution of vegetation types on Mt. Korobaba (modified from Kirkpatrick and Hassal 1985). Areas in boxes show the distribution of vegetation types: A, diverse lowland rain forest; B, Calophyllum, Trichospermum, Terminalia forest; C, Canarium, Syzygium, Garcinia forest; D, Dacrydium nidulum forest; E, stunted montane forest.

mainly of mangroves, and 119 species $(75 \%$ of which are indigenous [Table 1]) have been identified on the island (Thaman et al. 2005, this issue). Eight vegetation communities have been recognized on a preliminary basis. Between the reef and beach are sea-grass beds that probably include all of Fiji's four seagrass species (Koshy 2001). Intertidal forest is composed of major zones, with the coastal Rhizophora zone being displaced by extensive stands of Brugiera gymnorrbiza that cover approximately one-third of the island. Other tidal formations that are not always inundated during high tides include mixed tidal forest dominated by Xylocarpus granatum or Excoecaria agallocha and sometimes Brugiera gymnorrbiza, and forest that is only inundated during spring tides and usually found on sandy substrates. The latter commonly is composed of several of the following species: the trees Inocarpus fagifer, Excoecaria agallocha, Cocos nucifera, Barringtonia asiatica, and Hibiscus tiliaceus; the shrub Heritiera littoralis; and the climber Smythea lanceolata. Noninundated vegetation types include inland coastal forest (including Cocos nucifera, Cerbera manghas, Pongamia pinnata, Xylocarpus pinnatum, Barringtonia asiatica, Inocarpus fagifer, Tarenna sambucina, Ficus vitiensis, and the introduced Annona glabra), strand vegetation (composed of common sandy beach species), and disturbed vegetation.

Although Nasoata/Valolo is the current focal site of the project, other studies within the Rewa Delta have been conducted. Koshy (2001) mapped and studied sea-grass communities on Nukubuco Reef, looking at the preferred habitats of Fiji's four sea-grass species. The Rewa Delta also harbors the Bonatoa wetlands, which is the largest $(890 \mathrm{ha})$ peat bog in Fiji (Ash and Ash 1984). This peat bog has several vegetation types related to the underlying substrate. Mixed grass and sedge vegetation is found on alluvial gley soils, and shallow peat is dominated by sedges. Deep peat of about $1 \mathrm{~m}$ depth harbors Pandanus tectorius, ferns, and patches of Sphagnum cuspidatum. In addition, there is an inner colluvium-peat zone that is dominated by sedges, grasses, and dicotyledonous herbs 
TABLE 3

Summary of Small Offshore Islands and Their Floristic Composition

\begin{tabular}{llccc}
\hline \hline Island & Substrate & Total No. of Species & Introduced & Endemic \\
\hline Namuka & Andesite & 77 & 23 & 5 \\
Makaluva & Sandy & 59 & 16 & 0 \\
Nukulau & Sandy & 65 & 23 & 0 \\
Mabualau & Limestone & 56 & 12 & 0 \\
Nukulevu & Sandy & 44 & 4 & 0 \\
\hline
\end{tabular}

Sources: Thaman $(1997 a, b)$, Ghazanfar et al. (2001).

(Ash and Ash 1984). The utilization of mangrove resources (flora and fauna) in Nadoria Village was studied by Thaman (1998).

The next study at this focal area should be the quantitative verification of the proposed vegetation types on Nasoata and $\mathrm{Va}$ lolo. With the help of aerial photographs it should then be possible to map the vegetation types. These should then be used for further ecological studies and long-term monitoring.

\section{DISCUSSION}

Most of the existing data on vegetation at the focal sites is insufficient, and data from Sovi and Waibau are almost absent. Good background data on species and plant communities exist only for Waisoi and Nasoata. More detailed ecological information has been collected only on the vegetation at Waisoi. The first priority of PABITRA should, therefore, be to accumulate necessary background information on all focal sites, a process that is currently under way. The first baseline surveys of parts of the Sovi Basin and parts of the Wabu focal site were conducted in May 2003 (Keppel 2003) and November 2003, respectively. This can now be followed by individual ecological research projects at the focal sites. An alternative approach would be combining ecological projects with checklisting of species and identification and mapping of plant communities present at the focal sites. A next step could then focus on establishing permanent plots.

Other studies, beside those already mentioned, have also been conducted within or adjacent to the PABITRA site. The floras of several small offshore islands have also been studied, showing that the small islands are dominated by widespread coastal species, resulting in low or no endemism (see Table 3).

I believe that besides the collation and collection of data from the focal sites, PABITRA needs to address several other issues in Fiji. Other areas could be chosen as additional focal sites. The Nadrau Plateau, for example, is the transition between the forest and grassland zones on Viti Levu and would be an interesting study location to include. Currently, Vatia, a peninsula near Tavua with remnants of deciduous coastal forest, is being targeted as an additional PABITRA focal site. Also, some areas, such as the Sovi Basin, are difficult to reach and the feasibility of establishing and maintaining permanent plots in such locations must be taken into consideration. Another question to be addressed is storage and usage of collected data. Standard databases and analysis programs should be considered.

\section{ACKNOWLEDGMENTS}

I thank Prof. Dieter Mueller-Dombois for his kind comments and suggestions.

\section{Literature Cited}

Ash, J. 1987. Demography of Cyathea hornei (Cyatheaceae), a tropical tree fern from Fiji. Aust. J. Bot. 35:331-342.

. 1988. Demography and production of Balaka microcarpa (Arecaceae), a tropical understorey palm from Fiji. Aust. J. Bot. 36:67-80.

—. 1992. Vegetation ecology of Fiji: 
Past, present, and future perspectives. Pac. Sci. 46:111-127.

Ash, J., and W. Ash. 1984. Freshwater wetland vegetation of Viti Levu, Fiji. N. Z. J. Bot. 22:377-391.

Berry, M. J., and W. J. Howard. 1973a. Fiji forest inventory. Vol. 1. The environment and forest types. Land Resource Study No. 12, Land Resource Division, Surbiton, Surrey, England.

- 1973b. Fiji forest inventory. Vol. 2. Catchment groups of Viti Levu and Kadavu. Land Resource Study No. 12, Land Resource Division, Surbiton, Surrey, England.

Brownlie, G. 1977. The pteridophyte flora of Fiji. (Beihefte zur Nova Hedwigia, Heft 55.) A. R. Ganther Verlag KG., Vaduz. Liechtenstein.

Condit, R. 1998. Tropical forest census plots: Methods and results from Barro Colorado Island, Panama and a comparison with other plots. Springer Verlag, Berlin, Germany.

Fuller, D., and J. L. Dowe. 1999. A new species of Balaka from Fiji. Palms 43:10-14.

Fuller, D., J. L. Dowe, and M. F. Doyle. 1997. A new species of Heterospathe from Fiji. Principes 41:59-69.

Ghazanfar, S., G. Keppel, and S. Khan. 2001. Coastal vegetation of small islands near Viti Levu and Ovalau, Fiji. N. Z. J. Bot. 39:587-600.

Hassal, D. C. 1980. Studies on Fijian vegetation 1. Highland forest and stream-bank formations near Wainisavulevu Creek, Viti Levu. South Pac. J. Nat. Sci. 1:26-44.

Hassal, D. C., and J. B. Kirkpatrick. 1985. The diagnostic value and host relationships of the dependent synusia in the forests of Mount Korobaba, Fiji. N. Z. J. Bot. 23:47-54.

Keppel, G. 1999. Population genetics, phylogeny, ecology and the conservation status of Cycas seemannii A. Br. (Cycadaceae). M.S. thesis, The University of the South Pacific, Suva, Fiji.

2003. Flora surveys. Pages 16-22 in C. Morrison, ed. Baseline flora and faunal survey of the Sovi Basin, Naitasiri, 5-17th May 2003. South Pacific Regional Her- barium, Wildlife Conservation Society, Birdlife International, and Wetlands International Technical Report, Suva, Fiji.

Keppel, G., J. C. Navuso, A. Naikatini, N. T. Thomas, I. A. Rounds, T. A. Osborne, N. Batinamu, and E. Senivasa. 2005. Botanical diversity at Savura, a lowland rain forest site along the PABITRA Transect, Viti Levu, Fiji. Pac. Sci. 59:175-191 (this issue).

Kirkpatrick, J. B., and D. C. Hassal. 1981. Vegetation of the Sigatoka sand dunes, Fiji. N. Z. J. Bot. 19:285-297.

1985. The vegetation and flora along an altitudinal transect through a tropical forest at Mount Korobaba, Fiji. N. Z. J. Bot. 23:33-46.

Koshy, L. P. 2001. An ecological and mapping study of the seagrass communities on Nukubuco Reef, Suva, Fiji. M.S. thesis, The University of the South Pacific, Suva, Fiji.

Lees, A. 1989. A representative National Park and Reserve system for Fiji's tropical forests. Maruia Society Policy Reports Series No. 9, May. Maruia Society, Nelson, New Zealand.

Loope, L. L., and T. W. Giambelluca. 1998. Vulnerability of island tropical montane cloud forests to climate change, with special reference to East Maui, Hawaii. Clim. Change 39:503-517.

Mueller-Dombois, D., and H. Ellenberg. 2002. Aims and methods of vegetation ecology. Blackburn Press, Caldwell, New Jersey.

Mueller-Dombois, D., and R. F. Fosberg. 1998. Vegetation of the tropical Pacific Islands. Springer Verlag, Berlin, Germany.

Mueller-Dombois, D., R. A. Thaman, J. O. Juvik, and K. Kitayama. 1999. The Pacific-Asia Biodiversity Transect (PABITRA), a new conservation biology initiative. Pages 13-20 in C. H. Chou, G. R. Walter, and C. Reinhardt, eds. Biodoversity and allelopathy: From organisms to ecosystems in the Pacific. Academia Sinica, Taipei, Taiwan.

Seemann, B. 1865-1873. Flora Vitiensis: A description of the plants of the Viti or Fiji Islands, with an account of their history, 
uses and properties. L. Reeve and Co., London, U.K.

Smith, A. C. 1979. Flora Vitiensis nova: A new flora of Fiji (spermatophytes only). Vol. 1. Pacific Tropical Botanical Garden, Lāwa'i, Kaua'i, Hawai'i.

. 1981. Flora Vitiensis nova: A new flora of Fiji (spermatophytes only). Vol. 2. Pacific Tropical Botanical Garden, Lāwa'i, Kaua'i, Hawai'i.

. 1985. Flora Vitiensis nova: A new flora of Fiji (spermatophytes only). Vol. 3. Pacific Tropical Botanical Garden, Lāwa'i, Kaua'i, Hawai'i.

. 1988. Flora Vitiensis nova: A new flora of Fiji (spermatophytes only). Vol. 4. Pacific Tropical Botanical Garden, Lāwa'i, Kaua'i, Hawai'i.

. 1991. Flora Vitiensis nova: A new flora of Fiji (spermatophytes only). Vol. 5. Pacific Tropical Botanical Garden, Lāwa'i, Kaua'i, Hawai'i.

. 1996. Flora Vitiensis nova: A new flora of Fiji (spermatophytes only): Comprehensive indices. Pacific Tropical Botanical Garden, Lāwa'i, Kaua'i, Hawai'i.

Still, C. H., P. N. Foster, and S. H. Schneider. 1999. Simulating the effects of climate change on tropical montane cloud forests. Nature (Lond.) 398 (6728): 608610.

Thaman, B. 1998. Community utilisation and valuation of mangrove resources in Fiji case studies of Sawa, Daku and Nadoria Villages and Kinoya and Tamavua-i-wai urban settlements, Viti Levu, Fiji. M.S. thesis, James Cook University, North Queensland, Australia.

Thaman, R. R. 1997a. Vascular plants of Ma- kaluva Reef Islet, Rewa Province, Viti Levu (A preliminary listing). Marine Studies Technical Report 97/3, The University of the South Pacific, Suva, Fiji. - 1997b. Vascular plants of Mabualau Reef Islet, Tailevu Province, Viti Levu (A preliminary listing). Marine Studies Technical Report 97/7, The University of the South Pacific, Suva, Fiji.

Thaman, R. R., G. Keppel, D. Whatling, B. Thaman, A. Naikatini, B. Thaman, N. Bolaqace, E. Sekinoco, and M. Masere. 2005. Nasoata mangrove island, the PABITRA coastal site for Viti Levu, Fiji Islands. Pac. Sci. 59:193-204 (this issue).

Tuiwawa, M. 1999. The flora, ecology and conservation of the botanical biodiversity of Waisoi and the southeasterm slopes of the Korobasaga Range in Namosi Province, Fiji. M.S. thesis, The University of the South Pacific, Suva, Fiji.

- 2005. Recent changes in the upland watershed forest of Monasavu, a cloud forest site along the PABITRA Gateway Transect on Viti Levu, Fiji. Pac. Sci. 59:159-163 (this issue).

van Balgooy, M. M. J. 1971. Plant geography of the Pacific. Blumea (supplement) 6:1222.

Watkins, A. J. 1995. A biogeographic database for seed plants of Fiji: A preliminary communication. South Pac. J. Nat. Sci. 46:111-127.

Wheatley, J. L. 1992. A guide to the common trees of Vanuatu. With lists of their traditional uses and Ni-Vanuatu names. Department of Forestry, Port Vila, Vanuatu.

Whitmore, T. C. 1980. A monograph of $A g a-$ this. Plant Syst. Evol. 135:41-69. 